\title{
Identifikasi Sel Human African Trypanosomiasis Pada Sel Darah Dengan Menggunakan K-Means Clustering
}

\author{
Anak Agung Ngurah Bagus Udayana Putra, I Ketut Gede Darma Putra, \\ Kadek Suar Wibawa \\ Program Studi Teknologi Informasi, Fakultas Teknik, Universitas Udayana \\ Bukit Jimbaran, Bali, Indonesia, telp. (0361) 701806 \\ E-Mail: agung.udayana.ttxa@gmail.com ikgdarmaputra@unud.ac.id suar wibawa@unud.ac.id
}

\begin{abstract}
Abstrak
Human African Trypanosomiasis atau merupakan suatu penyakit yang disebabkan oleh parasit yang ada pada darah manusia. Parasit tersebut muncul akibat gigitan dari lalat tsetse yang umumnya terjadi di wilayah pedesaan. Parasit yang dikeluarkan oleh lalat tsetse tersebut berbentuk seperti jentik nyamuk yang terdapat dalam sel darah dengan warna yang sangat mirip dengan sel darah manusia. Selama ini, cara yang dilakukan untuk mengidentifikasi sel parasit tersebut adalah dengan menggunakan citra mikroskop dari sel darah dan menganalisanya secara manual. Dengan menggunakan metode K-means Clustering pada 8 buah citra sel darah, 85,63\% dari citra tersebut telah mampu diidentifikasi apakah sel darah yang diteliti terinfeksi sel parasit Trypanosome atau tidak.
\end{abstract}

Kata Kunci : African Trypanosomiasis, African Sleeping Sickness, K-Means Clustering, Lalat Tsetse

Abstract
Human African Trypanosomiasis or is a disease caused by parasites present in human blood. The parasite arises from the bite of tsetse flies that generally occur in rural areas. The parasite released by the tsetse fly is shaped like a mosquito larva contained in blood cells with a color that is very similar to human blood cells. So far, the method used to identify parasitic cells is to use a microscope image of blood cells and analyze them manually. By using the K-means Clustering method on 8 images of blood cells, $85.63 \%$ of the images have been able to be identified whether the blood cells studied were infected with Trypanosome parasitic cells or not.

Keywords: African Trypanosomiasis, African Sleeping Sickness, K-Means Clustering, Tsetse Fly

\section{Pendahuluan}

Human African Trypanosomiasis (HAT) atau penyakit tidur merupakan penyakit yang diduga telah ditaklukkan pada tahun 1960-an, yang muncul kembali sebagai masalah kesehatan masyarakat yang serius di sebagian besar wilayah sub-Sahara Afrika [1]. HAT tersebar hingga 23 dari 25 negara di bagian sub-Sahara pada periode $2000-2009$ [2]. Diperkirakan bahwa 300.000-500.000 orang saat ini terinfeksi dan 100.000 kematian disebabkan setiap tahun oleh penyakit ini [3]. Penyebab utama penyakit ini adalah dari lalat tsetse yang hidup di Afrika. Distribusi dan prevalensi lalat tersebut dipengaruhi oleh faktor-faktor spasial seperti iklim, vegetasi, dan pemanfaatan lahan [4]. Ada dua subspesies Trypanosome Brucei yang menyebabkan penyakit tidur, yakni Trypanosome Brucei Gambiense yang menyebabkan bentuk penyakit tidur yang lebih kronis dan banyak terjadi di Afrika barat/tengah dan Sudan selatan, dan Trypanosome Brucei Rhodesiense yang menyebabkan bentuk yang lebih akut dari penyakit tidur dan lebih dominan di Afrika timur dan selatan [5].

Sebuah penelitian dilakukan selama empat tahun di kawasan hutan Daloa di Côte d'Ivoire untuk menilai tingkat infeksi trypanosome pada lalat tsetse, dan resiko infeksi trypanosomiasis [6]. Sel tersebut ditemukan hanya pada 34 lalat tsetse dan memiliki tingkat infeksi yang sangat rendah ( 0,18 persen). Meskipun lalat tsetse yang terinfeksi ditangkap di semua habitat yang diperiksa, tingkat infeksi relatif lebih tinggi di sepanjang jalan setapak $(0,44$ persen), di lahan pertanian ( 0,20 persen) dan sekitar mata air hutan (0,27 persen) dibandingkan dengan tepi desa (0,06 persen) dan batas hutan (0,05 persen). Di antara 34 lalat tsetse yang terinfeksi Trypanosome brucei, hanya 0,05 persen yang memiliki parasit secara eksklusif di 
kelenjar ludah mereka. Hasil menunjukkan bahwa jalan setapak, perkebunan kopi dan kakao dan mata air hutan adalah biotop potensial di mana risiko infeksi oleh $\mathrm{T}$. brucei adalah yang paling tinggi [7].

Saat ini, belum ditemukan vaksin untuk mencegah Human African Trypanosomiasis. Trypanosomiasis dilaporkan menelan biaya lebih dari \$ 4 miliar Dolar Amerika Serikat setiap tahun. Beban HAT masih tinggi di Angola, Republik Demokratik Kongo, Uganda dan Sudan; dan beban yang tinggi ini secara langsung berkaitan dengan faktor-faktor seperti menurunnya aktivitas pengawasan dan pengendalian, perang, parasit, resistensi Trypanosome terhadap obat-obatan dan insektisida, migrasi penduduk, dan kerentanan penyakit inang [8].

Manusia yang diserang penyakit African Trypanosomiasis ini dalam sel darahnya akan terdapat sel berbentuk mirip seperti jentik nyamuk, yang disebut dengan Trypomastigotes. Sel parasit ini hidup dan berkembang biak dalam darah dan dalam kelenjar getah bening manusia, namun dalam beberapa kasus sel ini bermigrasi ke sistem saraf pusat [9]. Penyakit ini terbilang mematikan, karena Trypanosome sangat rentan terhadap antibodi, karena mereka hidup sepenuhnya terkena antibodi dalam darah. Penyakit ini dapat bertahan selama satu tahun atau lebih, bahkan hingga manusia yang terinfeksi tersebut meninggal [10]. Maka dari itu, diperlukan sebuah sistem dalam mengidentifikasi Sel parasit agar penanganan medis yang tepat dapat dilakukan.

Dalam penelitian mengenai deteksi sel secara otomatis, telah dilakukan oleh Andre Mahaputra, yakni mengidentifikasi Burr Cell dalam Eritrosit menggunakan Region Properties [11]. Dalam penelitian tersebut, penulis membuat sebuah aplikasi yang dapat digunakan untuk mendeteksi apakah dalam darah terdapat kelainan pada sel darah tersebut. Proses identifikasinya menggunakan Region Properties yang bekerja dengan mendeteksi objek yang berbentuk tidak normal yang menghasilkan akurasi sekitar $89,13 \%$. Penelitian lainnya mengenai deteksi sel secara otomatis dilakukan oleh Novar Setiawan, yakni Klasifikasi Citra Mammogram menggunakan Metode K-Means, GLCM, dan SVM [12]. Dalam penelitian tersebut, penulis memanfaatkan metode K-Means Clustering untuk memfilter objek dalam citra, kemudian dilakukan proses ekstraksi fitur menggunakan GLCM (Gray Level Co-Occurance Matrix), dan kemudian hasilnya akan diklasifikasi menggunakan metode SVM (Support Vector Machine) yang menghasilkan akurasi sebesar $80 \%$.

Dalam penelitian ini, dilakukan proses identifikasi sel parasit Trypomastigotes pada sel darah menggunakan metode K-Means Clustering. Namun, sebelum dilakukan proses clustering, citra akan dilakukan konversi ke ruang warna $L^{*} A^{*} B$ untuk mempermudah proses clustering. Proses dalam mengidentifikasi sel parasit Trypomastigotes adalah dengan menggunakan Region Properties yang memanfaatkan luas dari objek yang terdeteksi.

\section{Metodologi Penelitian}

Penelitian ini menggunakan data dari sel darah yang berjumlah 8 buah citra yang terdiri dari 3 buah citra yang terinfeksi Trypanosome Brucei dan 4 sel darah normal. Pembuatan aplikasi ini menggunakan bahasa pemrograman Matlab versi R2018a.

Aplikasi identifikasi sel Human African Trypanosomiasis menggunakan metode K-Means clustering untuk memisahkan antara sel darah dengan Sel Trypomastigotes. Tahap yang dilakukan untuk memperoleh citra Sel Trypomastigotes ini adalah dengan mengakuisisi citra terlebuh dahulu, kemudian dilakukan proses pengubahan ke ruang warna $L^{*} A^{*} B$, lalu dilakukan segmentasi dengan metode K-Means clustering, lalu dilakukan post-processing, kemudian dilakukan proses deteksi apakah terdapat Trypanosome Brucei dalam sel darah tersebut atau tidak. Alur proses dari program ini akan digambarkan pada Gambar 1.

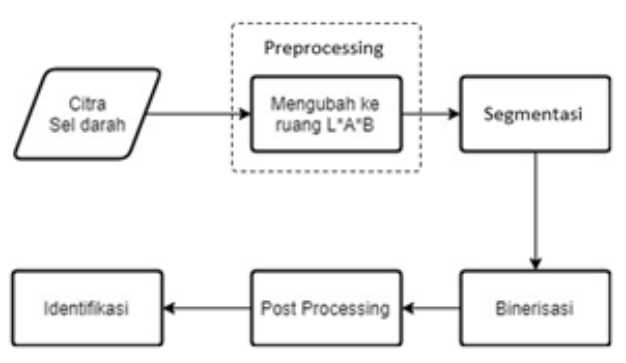

Gambar 1. Gambaran Umum 


\subsection{Ruang warna $L^{*} A^{*} B$}

Ruang warna $L a b$ adalah ruang lawan warna dengan dimensi $L$ untuk cahaya dan a dan b untuk dimensi lawan warna. Warna lab dirancang untuk mendekati visi manusia. Ini bertujuan untuk keseragaman persepsi, dan komponen $L$ yang sangat cocok dengan persepsi manusia tentang cahaya [13]. Dengan demikian dapat digunakan untuk membuat koreksi keseimbangan warna yang akurat dengan memodifikasi kurva output dalam komponen a dan $b$, atau untuk menyesuaikan kontras cahaya menggunakan komponen L. Tiga koordinat CIELAB mewakili terangnya warna $\left(L^{*}=0\right.$ menghasilkan hitam dan $L^{*}=100$ menunjukkan putih menyebar), posisinya antara merah / magenta dan hijau (a * nilai negatif menunjukkan hijau sementara nilai positif menunjukkan magenta) dan posisinya antara kuning dan biru ( $b{ }^{*}$, nilai negatif menunjukkan nilai biru dan positif menunjukkan warna kuning) [14]. Gambar 2 merupakan contoh citra dengan ruang warna $L^{*} A^{*} B$.

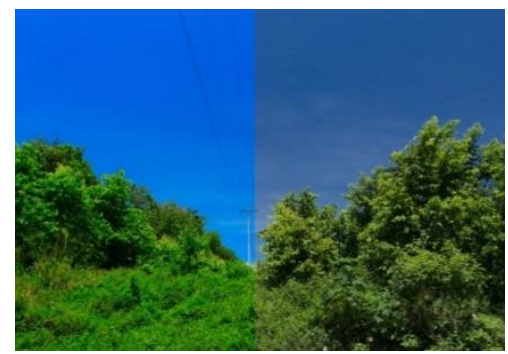

Gambar 2. Perbaikan citra dengan ruang warna LAB (kiri) citra normal (kanan)

Tahap pengubahan ruang warna citra inputan ke ruang warna $L^{*} A^{*} B$ dilakukan karena citra sel Trypomastigotes memiliki warna yang hampir mirip dengan citra sel darah merah manusia. Proses ini membuat tiap objek pada citra memiliki warna yang berbeda, sehingga aplikasi dapat mendeteksi tiap objek yang ada dalam citra inputan.

\subsection{Segmentasi}

Segmentasi citra merupakan proses pengelompokan citra digital menjadi beberapa wilayah atau objek yang terdiri dari kumpulan piksel dari berbagai properti atau karakteristik yang sama yang diberi label berbeda untuk mewakili berbagai wilayah atau objek [15]. Proses segmentasi citra disini menggunakan algoritma K-Means Clustering.

Algoritma k-means bekerja dengan mengelompokkan " $n$ " jumlah objek berdasarkan karakteristik yang sama ke dalam partisi $\mathrm{k}$, di mana $\mathrm{k}<\mathrm{n}$ [16]. Proses pengelompokan itu disebut dengan clustering. Clustering adalah metode yang mengelompokkan data ke dalam kelompok, di mana objek dalam masing-masing kelompok memiliki tingkat kesamaan yang tinggi, tetapi tidak sama dengan objek dalam kelompok lain [17].

Algoritma K-means adalah algoritma pengelompokan yang paling umum digunakan karena dapat dengan mudah diimplementasikan dan merupakan yang paling efisien. Masalah utama dengan algoritma ini adalah sensitif terhadap pemilihan jumlah cluster sehingga dapat mempengaruhi hasil clustering [18].

Metode K-Means Clustering digunakan bertujuan untuk memisahkan tiap objek sesuai dengan jumlah inputan cluster yang telah ditentukan [12]. Pada studi kasus ini, objek yang akan diambil adalah SelTrypomastigotes dari citra sel darah manusia. Pada studi kasus ini, metode ini akan mengelompokkan citra menurut kesamaan warnanya, berdasarkan nilai $\mathrm{k}$ yang ditentukan.

\subsection{Binerisasi}

Citra biner adalah citra yang memiliki hanya 2 informasi, yaitu piksel bernilai 1 yang didefinisikan sebagai objek dan piksel bernilai 0 yang didefinisikan sebagai background (nonobjek) [19]. Proses binerisasi digunakan untuk memudahkan post processing di tahap selanjutnya karena hanya citra biner yang dapat dilakukan proses morfologi, filtering, dan lain sebagainya. 
Sebelum dapat lanjut ke proses selanjutnya, dilakukan proses untuk menghitung nilai dari piksel putih pada citra biner untuk menentukan apakah terdapat sel Trypomastigotes atau tidak. Apabila terdeteksi, maka dilanjutkan ke proses selanjutnya.

\subsection{Post-processing}

Proses post-processing dilakukan karena pada tahap segmentasi masih terdapat beberapa noise yang dapat mengacaukan proses segmentasinya. Maka, dilakukan proses grayscaling, kemudian dilakukan binerisasi, lalu dilakukan proses median filtering untuk menghilangkan bagian kecil dari citra yang ikut tersegmentasi, lalu dilakukan proses erosi, kemudian filling holes, dan yang terakhir dilakukan proses dilasi agar objek yang dicari terlihat lebih jelas. Semua proses tersebut dilakukan untuk memperoleh sel Trypomastigotes dari citra sel darah yang telah diinputkan.

\subsection{Deteksi Citra}

Dalam proses pendeteksian citra, citra yang akan dicari adalah citra dari sel parasit Trypomastigotes pada sel darah manusia. Sel Trypomastigotes berukuran hampir sebesar sel darah manusia, namun berbentuk menyerupai jentik nyamuk dan gerakannya begitu cepat. Gambar 3 merupakan citra dari sel Trypomastigotes.

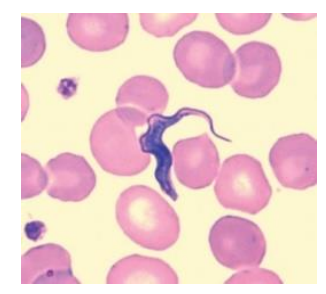

Gambar 3. Sel Trypomastigotes dalam sel darah manusia

Proses deteksi citra memanfaatkan hasil dari post processing pada tahap sebelumnya. Citra yang didapat pada proses sebelumnya kemudian dilakukan pengukuran ukuran rata-rata dari objek. Apabila terdapat objek yang lebih kecil dari objek yang diinginkan, maka objek kecil tersebut akan dihilangkan. Proses ini memanfaatkan fungsi Regionprops. Regionprops merupakan salah satu fungsi dalam image processing toolbox yang telah tersedia di Matlab yang memungkinkan pengguna untuk mengekstrak sekumpulan properti dari sebuah citra. Citra tersebut dapat diberi label menggunakan nilai yang diperoleh dari properti tersebut. Fitur-fitur yang dapat diesktrak adalah Area, Centroid, Orientation, Major Axis Length, Minor Axis Length, Diameter, Extrema dan Eccentricity [20].

\section{Kajian Pustaka}

\subsection{African Trypanosomiasis}

African Trypanosomiasis adalah penyakit kompleks ada di bagian sub-Sahara Afrika, yang mempengaruhi manusia dan hewan. Hal ini disebabkan oleh parasit trypanosome dan ditularkan oleh lalat tsetse (Glossina) yang hanya ada di sub-Sahara Afrika. Dampak dari penyakit ini meluas lebih dari 37 negara dan sekitar 10 juta km dari luas daratan. Dari 10 juta $\mathrm{km}$ ini, sekitar tiga juta tertutup oleh hutan hujan khatulistiwa, sementara daerah yang tersisa mengandung beberapa bagian benua yang berair, sehingga menyangkal manusia dan ternak berpotensi menjadi lahan subur dan padang rumput [21].

Sel ini berada di dalam sel darah manusia. Sel ini secara terus menerus akan berkembang biak dalam darah manusia maupun makhluk hidup lainnya. Gambar 4 merupakan contoh sel Trypomastigotes dalam sel darah manusia. 


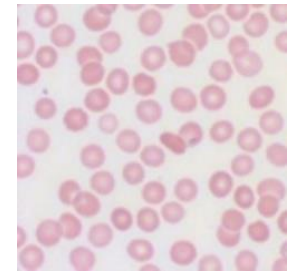

(a)

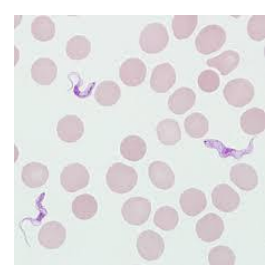

(b)

Gambar 4. (a) Sel darah normal (b) Sel darah terinfeksi

Pada sel darah normal (a) terdapat hanya sel darah yang berbentuk seperti donat dan tidak terdapat sel lainnya. Sedangkan pada sel darah yang terinfeksi sel Trypomastigotes terlihat bahwa dalam darahnya terdapat sel darah dan juga sel parasit yang berbentuk seperti jentik nyamuk. Sel itulah yang disebut sel Trypomastigotes yang diteliti pada penelitian ini.

\section{$3.2 \quad K$-Means}

K-means merupakan suatu algoritma pengelompokan yang memanfaatkan metode partisi. K-means mengelompokkan data menjadi sebuah cluster. Metode ini bekerja dengan mencari pusat kluster dan juga batas-batas kluster melalui proses perulangan. Langkah awal dari metode k-means adalah menentukan jumlah pusat kluster dalam dataset. Penentukan pusat cluster awal ditentukan secara acak. Secara iteratif, pusat kluster tersebut akan diperbaiki sehingga merepresentasikan pusat-pusat $\mathrm{k}$ kluster. Kemiripan data tersebut dengan pusat kluster maupun dengan data lain dihitung menggunakan fungsi jarak Euclidean. Proses ini akan terus diulang hingga centroid mencapai nilai yang optimal [22].

\subsection{Number of Nonzero Matrix Element}

Number of Nonzero Matrix Element atau disingkat dengan NNZ merupakan sebuah fungsi yang ada pada Matlab yang berfungsi untuk menghitung jumlah matriks bernilai 1 pada sebuah citra biner. Fungsi ini dapat digunakan untuk menghitung luas dari suatu objek yang terdeteksi pada suatu citra biner.

\section{Percobaan dan Hasil}

\subsection{Persiapan Data}

Data yang akan digunakan adalah citra dari sel darah normal dan juga sel darah yang telah terinfeksi sel parasit. Total citra yang digunakan berjumlah 8 buah citra yang terdiri dari 4 citra sel darah normal dan 4 citra sel darah yang telah terinfeksi sel parasit Trypanosome.
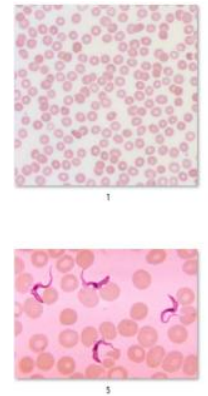
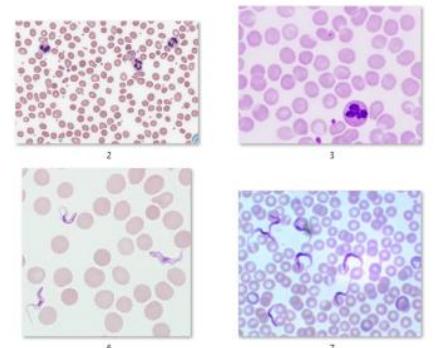

Gambar 5. Data citra

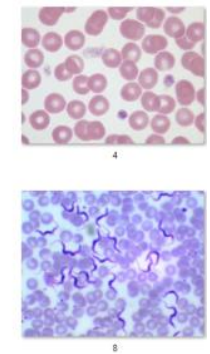

Gambar 5 merupakan seluruh citra yang akan dilakukan pengujian pada aplikasi ini. Seluruh citra yang digunakan diperoleh dari internet dengan warna latar yang sedikit berbeda antara satu dengan yang lainnya. Berdasarkan penjelasan sebelumnya, Sel Trypomastigotes akan berbentuk menyerupai jentik nyamuk yang bergerak dalam darah.

\subsection{Tampilan Awal}

Program ini dibuat dengan menggunakan bahasa pemrograman Matlab dengan memanfaatkan sebuah GUI (Graphical User Interface) agar lebih mudah dalam memilih citra yang akan di proses serta lebih mudah dalam melihat hasil pemrosesan dari aplikasi ini. 
Gambar 6 merupakan tampilan awal dari Aplikasi Deteksi Sel Human African Trypanosomiasis Pada Sel Darah Dengan Menggunakan K-Means Clustering.

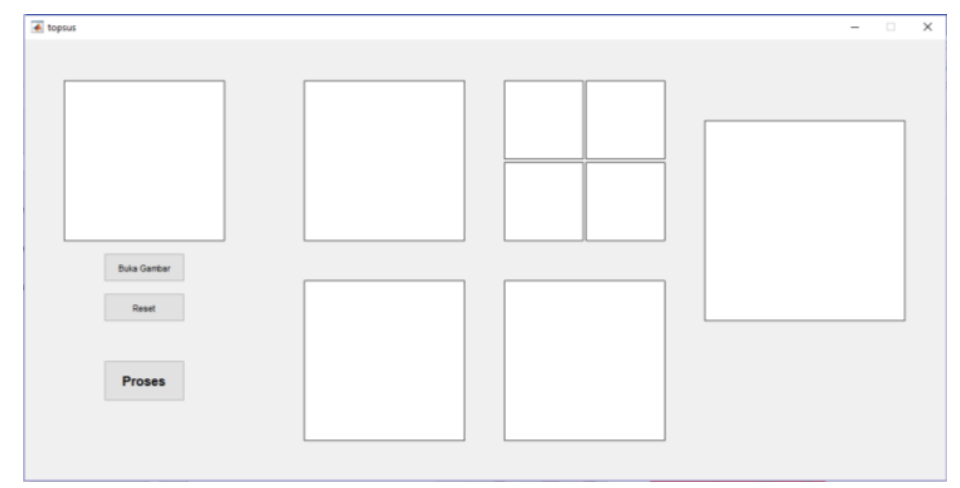

Gambar 6. Tampilan awal aplikasi Identifikasi Sel Human African Trypanosomiasis

\subsection{Preprocessing}

Tahap preprocessing menggunakan ruang warna $L^{*} A^{*} B$. Citra inputan yang memiliki format ruang warna RGB kemudian diubah menjadi format $L^{*} A^{*} B$ karena citra sel darah yang digunakan berisi objek yang memiliki warna hampir mirip, yakni antara sel parasit dengan sel darah normal. Setelah terlihat adanya perbedaan warna pada citra inputan, barulah dapat dilakukan proses clustering.

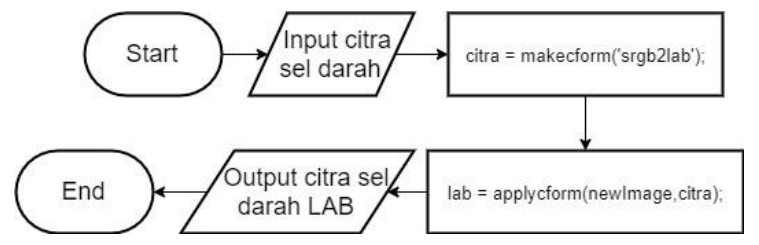

Gambar 7. Konversi citra ke ruang warna $L^{*} A^{*} B$

Gambar 7 merupakan alur dari proses konversi ruang warna citra dari RGB ke ruang warna $L^{*} A^{*} B$. Hasil konversi dari citra tersebut nantinya akan dilakukan proses segmentasi agar dapat memisahkan antara latar belakang dengan objek yang ingin di deteksi.

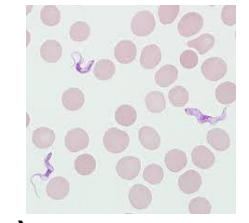

(a)

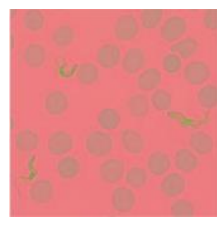

(b)

Gambar 8. (a) Citra Asli (b) Citra Hasil Preprocessing

Gambar 8 merupakan citra asli dan citra hasil konversi ke ruang warna $L^{*} A^{*} B$. Citra tersebut dikonversi karena proses $K$-Means Clustering membutuhkan citra dengan ruang warna $L^{*} A^{*} B$ agar proses segmentasinya dapat berjalan dengan sebagaimana mestinya.

\subsection{Segmentasi}

Metode K-Means Clustering menggunakan perhitungan jarak euclidean distance sebagai pengukur jarak dari masing-masing pusat cluster. Jarak Euclidean adalah metode yang digunakan untuk mengukur antara dua titik. Jarak ini diberikan oleh rumus Pythagoras [20]. Proses segmentasi ini sangat penting, karena proses ini yang akan mendapatkan citra dengan intensitas nilai yang paling berbeda dari citra sel darah manusia. Penerapan metode ini telah berhasil mensegmentasi sel darah dengan penentuan nilai $\mathrm{k}=4$, dimana citra akan 
dikelompokan dalam 4 cluster warna, kemudian dilakukan proses labelling agar hasil clusteringnya lebih jelas terlihat. Kode program 1 merupakan kode program yang digunakan dalam proses K-Means Clustring.

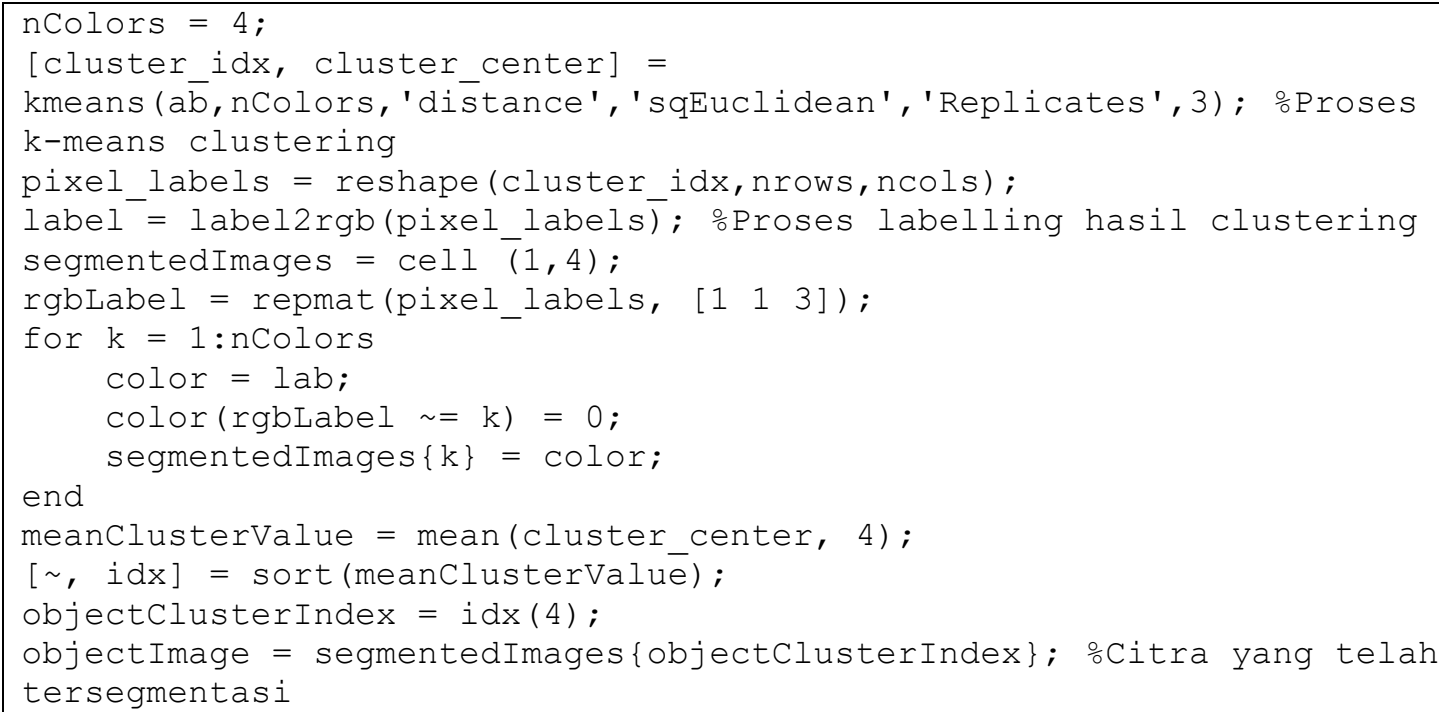

\section{Kode Program 1. Proses K-Means Clustering}

Sesuai dengan jumlah cluster yang telah ditentukan, citra $L^{*} A * B$ pada proses sebelumnya dibagi menjadi 4 bagian cluster agar citra dari sel Trypomastigotes dapat dipisahkan dari sel darah dan latar belakang. Gambar 9 merupakan citra hasil K-Means Clustering dari citra $L^{*} A^{*} B$.

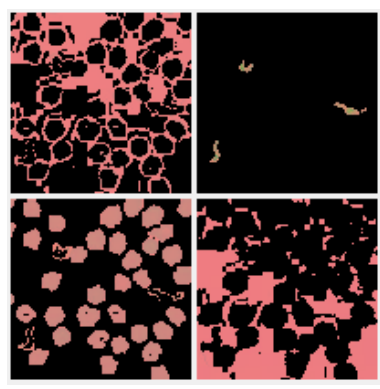

Gambar 9. Citra Hasil K-Means

Setelah didapatkan citra yang ingin dilakukan pemrosesan, maka citra tersebut dimasukkan ke dalam suatu variabel agar dapat dengan mudah dilakukan preprocessing. Gambar 10 merupakan citra hasil segmentasi yang akan dilakukan preprocessing.

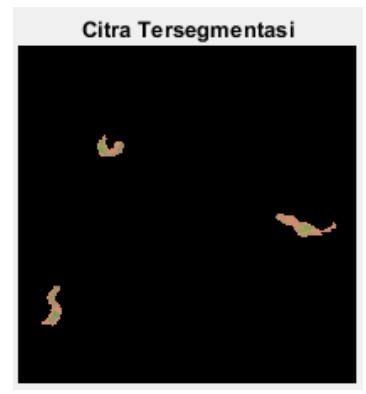

Gambar 10. Citra hasil segmentasi 


\subsection{Post-processing}

Tahap post-processing merupakan tahapan perbaikan citra yang dilakukan jika, hasil segmentasi citra dianggap belum baik atau masih terdapat noise. Kode Program 2 merupakan kode program serta hasil dari proses preprocessing dari aplikasi ini.

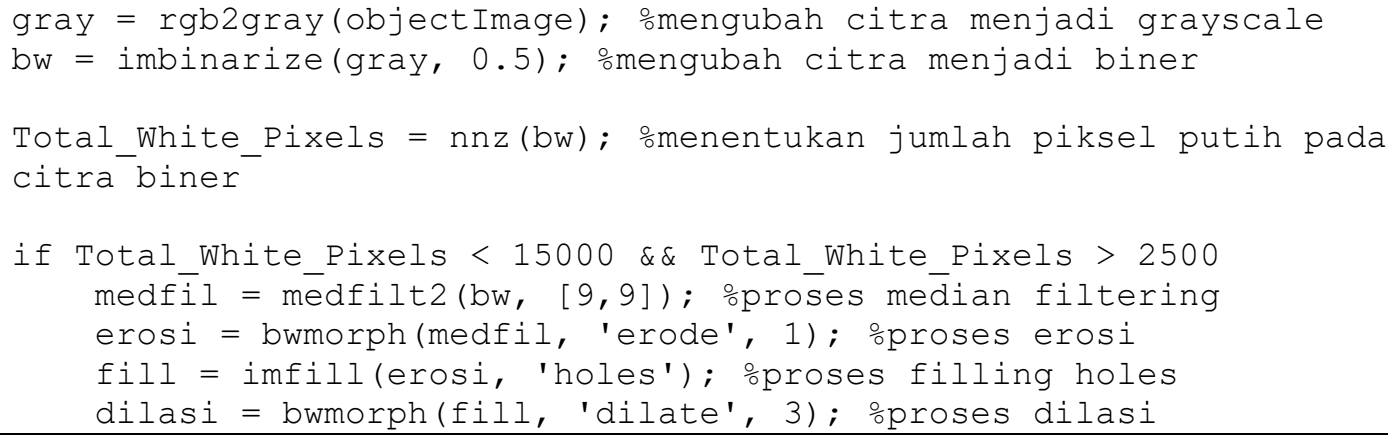

Tahap ini terdiri atas beberapa proses, yaitu grayscalling yang dilanjutkan dengan proses binerisasi. Sebelum lanjut ke proses selanjutnya, citra tersebut akan diuji apakah pada citra tersebut terdapat sel parasit Trypanosome atau tidak. Karena jumlah sel parasit tersebut lebih sedikit dari jumlah sel darah manusia, maka pada aplikasi ini dilakukan proses validasi, dengan nilai piksel putih antara 2.500 hingga 15.000 . Nilai tersebut dipilih karena citra hasil segmentasi belum tentu bersih dan sudah pasti terdapat noise, dan noise tersebut berada pada rentang nilai putih yang kurang dari 2.500 dan juga lebih dari 15.000. Apabila rentang nilai tercapai, maka proses selanjutnya adalah melakukan median filtering, lalu dilakukan erosi, kemudian dilakukan filling holes, dan proses terakhir adalah dilasi.

\section{a. Median Filtering}

Median Filtering adalah teknik filtering suatu citra dimana proses ini sering digunakan untuk menghilangkan noise dari gambar atau sinyal. Pengurangan noise tersebut adalah langkah pre-processing untuk meningkatkan kualitas hasil pemrosesan untuk tahap selanjutnya. Gambar 11 merupakan citra hasil Median Filtering.

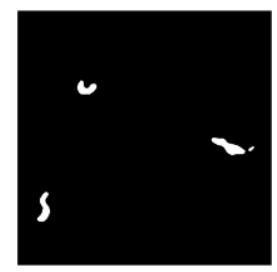

Gambar 11. Citra hasil Median Filtering

\section{b. Erosi}

Erosi merupakan suatu proses dalam pengolahan citra yang berfungsi untuk merampingkan area dari citra yang dideteksi. Dalam aplikasi ini, proses erosi berfungsi dalam mengurangi noise yang tidak terhapus dalam proses median filtering sebelumnya. Gambar 12 merupakan citra hasil proses erosi.

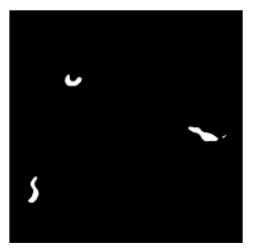

Gambar 12. Citra hasil Erosi 


\section{c. Filling Holes}

Filling Holes merupakan suatu proses yang digunakan dalam mengisi celah/lubang dari sebuah citra sehingga citra yang bentuknya telah terkikis dalam proses sebelumnya dapat diperbaiki kembali sehingga membentuk sebuah objek yang utuh. Gambar 13 merupakan citra hasil proses filling holes.

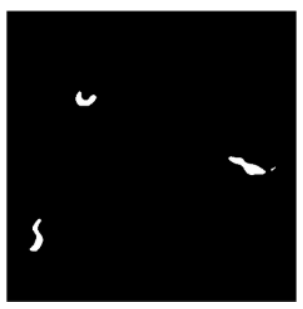

Gambar 13. Citra hasil Filling Holes

\section{d. Dilasi}

Dilasi merupakan suatu proses yang berlawanan dengan proses erosi, yakni mempertebal area dari citra yang terdeteksi. Dalam aplikasi ini, proses erosi dilakukan agar citra yang terdeteksi menjadi citra yang lebih tebal sehingga lebih mudah untuk dilakukan pendeteksian. Gambar 14 merupakan citra hasil proses dilasi.

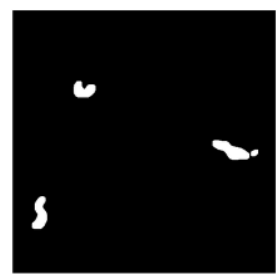

Gambar 14. Citra hasil Dilasi

\subsection{Proses identifikasi}

Proses identifikasi sel parasit Trypanosome ini menggunakan Regionprops. Atribut regionprops yang digunakan adalah area agar objek-objek kecil yang masih lolos dari proses sebelumnya tidak terdeteksi sebagai sel penyakit. Kode program 3 merupakan kode program yang digunakan dalam mendeteksi Sel Trypomastigotes.

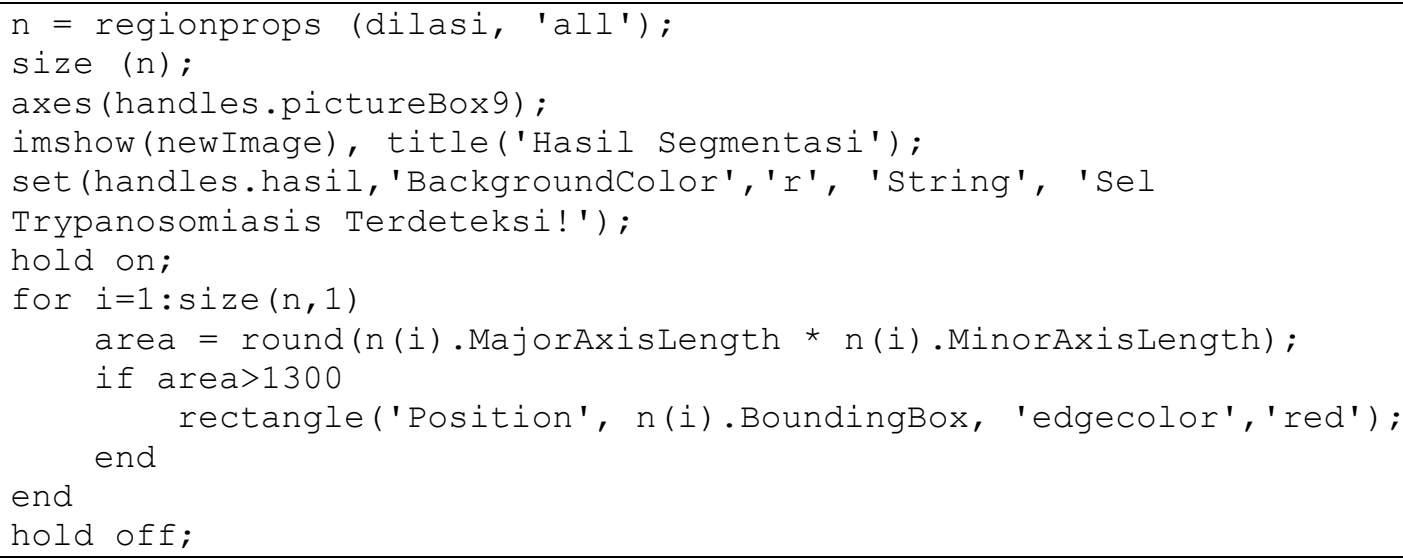

Kode Program 3. Proses deteksi sel parasit Human African Trypanosomiasis

Dari 8 citra inputan yang digunakan, 4 citra sel darah adalah sel yang normal dan 4 citra sel darah lainnya adalah sel darah yang terkena parasit. Gambar 15 merupakan contoh uji coba sistem menggunakan salah satu citra uji. 


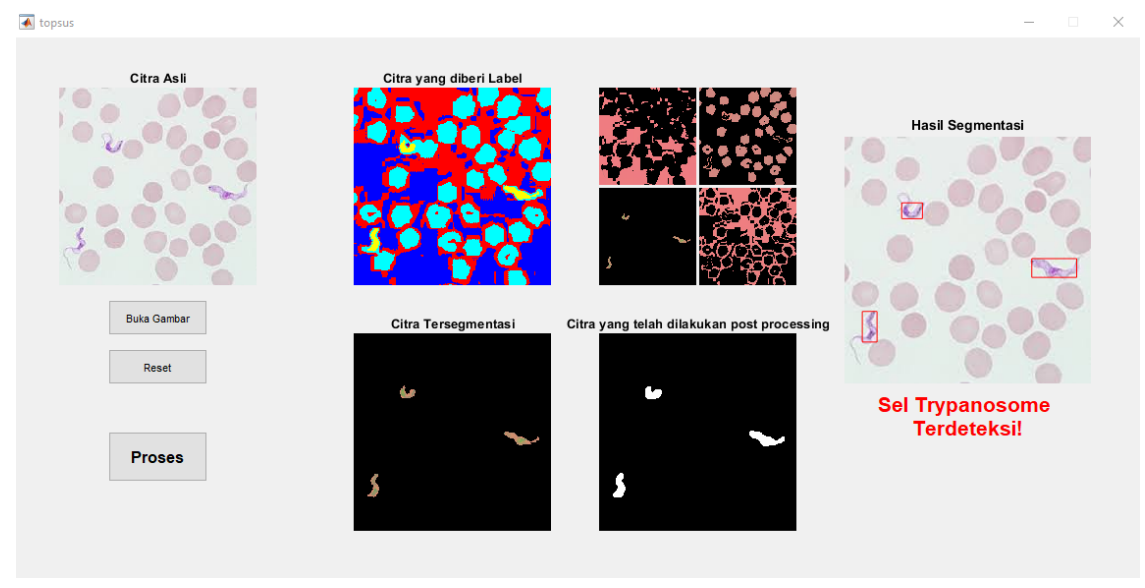

Gambar 15. Tampilan hasil proses identifikasi dari aplikasi

Hasil uji coba sistem akan memberikan sebuah label dari objek yang dianggap sebagai sel parasit dari citra sel darah. Proses ini memanfaatkan BoundingBox sehingga tiap objek yang dianggap sebagai sel parasit secara otomatis diberikan label pada citra hasilnya.

\subsection{Hasil Uji Coba}

Hasil uji coba adalah proses untuk mendapatkan hasil akurasi ketepatan Aplikasi Identifikasi Sel Human African Trypanosomiasis dalam sel darah menggunakan K-Means Clustering pada citra mikroskop. Perhitungan akurasi dilakukan dengan membandingkan jumlah Sel Trypanosomiasis yang didapat dari aplikasi dengan jumlah Sel Trypanosomiasis yang didapat dari hasil pengamatan mata dari citra yang diujikan dengan persamaan sebagai berikut.

$\operatorname{Akurasi}(\%)=\frac{\sum \text { Trypanosomiasis terdeteksi }}{\sum \text { Trypanosomiasis pengamatan }} \times 100 \%$

Perhitungan persamaan 1 tersebut diuji coba pada aplikasi menggunakan 8 buah citra sel darah yang telah dijabarkan sebelumnya. Tabel 1 merupakan hasil uji coba dari aplikasi yang dirancang.

Tabel 1 Hasil uji coba

\begin{tabular}{|c|c|c|c|}
\hline Citra & Jumlah sel parasit & $\begin{array}{l}\text { Jumlah yang } \\
\text { Teridentifikasi }\end{array}$ & Akurasi \\
\hline & 0 & 0 & $100 \%$ \\
\hline 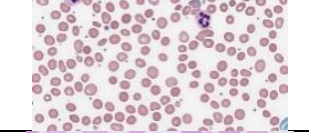 & 0 & 0 & $100 \%$ \\
\hline 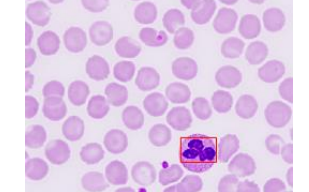 & 0 & 1 & $0 \%$ \\
\hline
\end{tabular}




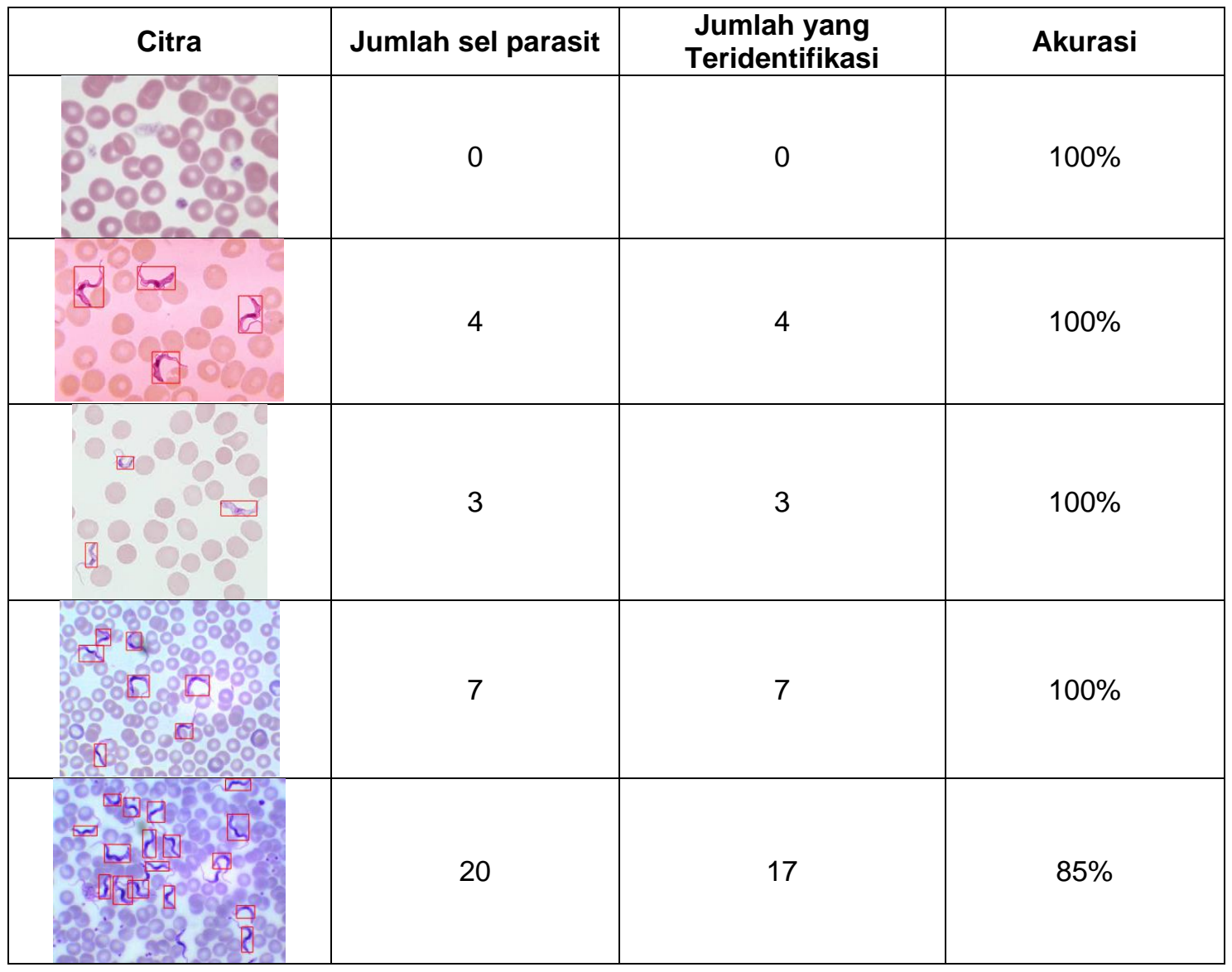

\section{Kesimpulan}

Sel parasit Trypomastigotes berbentuk seperti cacing dengan jumlah yang lebih sedikit dibanding dengan jumlah sel darah merah. Sel ini dalam realitanya akan bergerak sangat cepat seperti jentik nyamuk dalam air. Dalam foto mikroskop, sel parasit ini berwarna sangat mirip dengan sel darah merah maupun sel darah putih. Namun dengan menggunakan aplikasi yang diusulkan ini, telah mampu mengidentifikasi apakah sel darah yang diteliti terinfeksi sel parasit Trypomastigotes atau tidak dengan tingkat akurasi sekitar $85,63 \%$ yang diambil dari rata-rata persentase akurasi pada tabel 1. Angka tersebut diperoleh karena dari 8 citra inputan, hanya 6 citra yang benar-benar akurat terdeteksi, sedangkan 2 citra lainnya akurasinya kecil dan bahkan terdapat hasil deteksi yang masih salah. Hal ini dapat terjadi karena warna maupun luas dari sel lain seperti sel darah putih memiliki warna dan luas yang mirip dengan Sel Trypomastigotes. Dari hasil pengujian tersebut menyatakan bahwa aplikasi yang dirancang mampu untuk mengidentifikasikan Sel Trypomastigotes dalam darah.

\section{Daftar Pustaka}

[1] S. C. Welburn, D. H. Molyneux, dan I. Maudlin, "Beyond tsetse-implications for research and control of human African trypanosomiasis epidemics," Trends Parasitol., vol. 32, no. 3 , hal. 230-241, 2016.

[2] C. Lumbala et al., "Human African trypanosomiasis in the Democratic Republic of the Congo: disease distribution and risk," Int. J. Health Geogr., vol. 14, no. 1, hal. 20, 2015.

[3] J. Alemu dan E. Gudina, "Prevalence of bovine trypanosomosis and its associated risk factors in selected woredas of Gambella Regional State, South West Ethiopia," J. Agric. Crop Res., vol. 6, no. 5, hal. 97-104, 2018.

[4] C. Isaac et al., "Molecular identification of different trypanosome species and subspecies in tsetse flies of northern Nigeria," Parasit. Vectors, vol. 9, no. 1, hal. 301, 2016.

[5] R. Opiro et al., "Genetic diversity and population structure of the tsetse fly Glossina fuscipes fuscipes (Diptera: Glossinidae) in Northern Uganda: Implications for vector control," PLoS Negl. Trop. Dis., vol. 11, no. 4, hal. e0005485, 2017. 
[6] P. G. E. Kennedy, "Update on human African trypanosomiasis (sleeping sickness)," J. Neurol., hal. 1-4, 2019.

[7] A. Zumla et al., "Host-directed therapies for infectious diseases: current status, recent progress, and future prospects," Lancet Infect. Dis., vol. 16, no. 4, hal. e47-e63, 2016.

[8] S. Aksoy, P. Buscher, M. Lehane, P. Solano, dan J. Van Den Abbeele, "Human African trypanosomiasis control: achievements and challenges," PLoS Negl. Trop. Dis., vol. 11, no. 4, hal. e0005454, 2017.

[9] M. Hashimoto, J. Morales, H. Uemura, K. Mikoshiba, dan T. Nara, "A novel method for inducing amastigote-to-trypomastigote transformation in vitro in Trypanosoma cruzi reveals the importance of inositol 1, 4, 5-trisphosphate receptor," PLOS One, vol. 10, no. 8, hal. e0135726, 2015.

[10] M. de los Milagros Cámara et al., "The trypomastigote small surface antigen (TSSA) regulates Trypanosoma cruzi infectivity and differentiation," PLoS Negl. Trop. Dis., vol. 11, no. 8, hal. e0005856, 2017.

[11] P. Andre Mahaputra dan I. M. Suwija Putra, "Identifikasi Burr Cell dalam Eritrosit Menggunakan Region Properties pada Citra Mikroskop," J. Ilm. Merpati (Menara Penelit. Akad. Teknol. Informasi); Vol. 6, No. 1, April 2018DO - 10.24843/JIM.2018.v06.i01.p01, Apr 2018.

[12] K. Novar Setiawan dan I. M. Suwija Putra, "Klasifikasi Citra Mammogram Menggunakan Metode K-Means, GLCM, dan Support Vector Machine (SVM)," J. IIm. Merpati (Menara Penelit. Akad. Teknol. Informasi); Vol. 6, No. 1, April 2018, Apr 2018.

[13] K. Raval, R. Shukla, dan A. K. Shah, "Color Image Segmentation using FCM Clustering Technique in RGB, L* a* b, HSV, YIQ Color spaces," Eur. J. Adv. Eng. Technol., vol. 4, no. 3, hal. 194-200, 2017.

[14] A. Nazaran et al., "Methodology for computing white matter nerve fiber orientation in human histological slices," J. Neurosci. Methods, vol. 261, hal. 75-84, 2016.

[15] P. Shivhare dan V. Gupta, "Review of image segmentation techniques including pre \& post processing operations," Int. J. Eng. Adv. Technol., vol. 4, no. 3, hal. 153-157, 2015.

[16] M. R. Hassan, R. R. Ema, dan T. Islam, "Color image segmentation using automated Kmeans clustering with RGB and HSV color spaces," Glob. J. Comput. Sci. Technol., 2017.

[17] M. A. Okeowo, H. Lee, F. Hossain, dan A. Getirana, "Automated generation of lakes and reservoirs water elevation changes from satellite radar altimetry," IEEE J. Sel. Top. Appl. Earth Obs. Remote Sens., vol. 10, no. 8, hal. 3465-3481, 2017.

[18] M. K. I. Rahmani, N. Pal, dan K. Arora, "Clustering of image data using K-means and fuzzy K-means," Int. J. Adv. Comput. Sci. Appl., vol. 5, no. 7, hal. 160-163, 2014.

[19] S. E. Indraani, I. D. Jumaddina, S. Ridha, dan S. Sinaga, "Implementasi Edge Detection Pada Citra Grayscale dengan Metode Operator Prewitt dan Operator Sobel," Maj. IIm. Inti, vol. 12, hal. 1-5, 2014.

[20] O. S. Sitompul dan E. B. Nababan, "Biased support vector machine and weighted-smote in handling class imbalance problem," Int. J. Adv. Intell. Informatics, vol. 4, no. 1, hal. 21-27, 2018.

[21] N. J. Shoumy, S. N. Yaakob, P. Ehkan, M. S. Ali, dan S. Khatun, "Feature Extraction for Neural Network Pattern Recognition for Bloodstain Image Analysis," Int. J. Appl. Eng. Res., vol. 11, no. 15, hal. 8583-8589, 2016.

[22] D. Rusjayanthi, "IDENTIFIKASI BIOMETRIKA TELAPAK TANGAN MENGGUNAKAN METODE POLA BUSUR TERLUKALISASI, BLOCK STANDAR DEVIASI, DAN KMEANS CLUSTERING," Lontar Komput. J. IIm. Teknol. Inf., 2015. 